\title{
Performance of Hemisphere Algorithm for Fast Form Factor Calculation
}

\author{
Noboru YAMADA*4, Tomoaki SHINODA and Hiroyuki TAKIZAWA \\ ${ }^{* 4}$ Department of Mechanical Engineering, Nagaoka University of Technology, \\ 1603-1 Kamitomioka machi, Nagaoka-shi, Niigata, 940-2188 Japan
}

\begin{abstract}
Development of fast and accurate algorithm of radiative heat transfer simulation is important in terms of efficient thermal design and simulation on diverse engineering area. This paper describes the performance of Hemisphere algorithm which has originally developed as a fast form factor calculation in the field of photorealistic three-dimensional computer graphics. We compared performance of the Hemisphere algorithm with two conventional methods which are frequently used in the field of radiative heat transfer simulation. As a result, the Hemisphere algorithm is significant faster than the conventional methods if one can accept an absolute error of $1.0 \times 10^{-5}$. In addition, the result indicates that the Hemisphere algorithm possibly suit for try and error process of large-scale model simulation due to its tolerable form factor distribution.
\end{abstract}

Key Words: Thermal Radiation, Heat Transfer, Heat Transfer Design, Computational Method

\section{1. 䊩}

近年，環境伝熱解析，高温・小型化する機器の熱設 計, 宇宙機器の加熱・放熱手段の最適化などの多様な 分野において，ふく射伝熱の正確かつ効率的な解析手 法が求められている. ふく射伝熱を正確に解析するた めには，対象とする任意形状物体の表面を微小要素に 分割し, 各要素間の形態係数を計算機メモリに格納し つつ，全要素間のふく射熱交換量を反復計算や大規模 行列計算によって算出するため, メモリ使用量および 計算時間が増大する. そのため市販パソコンで大規模 解析の試行錯誤は容易でない，一方，コンピュータグ ラフィックス (CG) 分野では, ふく射 (可視光) の振 る舞いを物理現象に則して計算し，リアルな画像を高 速生成するアルゴリズムや尃用ハードウェアが急速に 発展しており,対象モデルの大規模化が進行している. CG 分野にお污る大域照明 (Global illumination) ${ }^{(1)}$ の計

* 原稿受付 2008 年 6 月 23 日。

*1 正員, 長岡技術科学大学工学部 (是 940-2188 長岡市上富岡 町 $1603-1$ ).

*2 長岡技術科学大学大学院機械創造工学専攻.

*3 東北大学サイバーサイエンスセンター(画 980-8578 仙台市 青葉区荒巻字青葉 6-3)

E-mail : noboru@mech.nagaokaut.ac.jp
算手法は, 本質的にふく射伝熱計算と変わらないため, これらをふく射伝熱解析に応用すれば前述の問題を軽 減できる可能性がある.

本研究では CG 分野で提案された形態係数の高速算 出手法であるへミスフィア法 (Hemisphere algorithm) の計算精度,計算時間を検証した結果について述べる.

\section{記 号}

\begin{tabular}{|c|c|}
\hline$A_{i}$ & 要素 $i$ の表面積 \\
\hline$F_{\text {ondysis } j}$ & : 要素 $j$ への形態倸数の解析解 \\
\hline$F_{\text {cal }, j}$ & : 要素 $j へ の$ 形態倸数 \\
\hline$F_{\text {abs_erorj }}$ & : 要素 $j$ への形態倸数の絶対誤差 \\
\hline $\bar{F}_{\text {errorj }}$ & : 要素 $j$ への形態倸数の平圴絶対誤言 \\
\hline$F_{i j}$ & : 要素 $i$ から要素 $j$ への形態 \\
\hline$l_{s}$ & ：楕円の単軸方向単位ベクトル \\
\hline$m_{s}$ & : 楕円の単軸力向単位ベクトル \\
\hline$N$ & ：解析モデルの全要素数 \\
\hline$R$ & : 要素間距離 $[\mathrm{m}]$ \\
\hline$T$ & : 温度 $[\mathrm{K}]$ \\
\hline$x, y, z$ & 座標 $[\mathrm{m}]$ \\
\hline$l, m, n$ & 単位法楾ベクトル成分 \\
\hline$X, Y, Z$ & : 座標 $[\mathrm{m}]$ \\
\hline リシャー & \\
\hline$\sigma$ & tefan-Boltzmann 係数 \\
\hline
\end{tabular}




\section{2. ヘミスフィア法による形態係数の算出}

2-1 形䅧係数 灰色面間のふく射伝熱解析の際 には, 多くの場合, 形態係数 (Form factor, View factor) $F_{i j}$ を求める必要がある. $F_{i j}$ は面積 $A_{i}$ の黒体平板 $i$ から 放射されたふく射エネルギーのうち，面積 $A_{j}$ の黑体平 板 $j$ に到達するふく射エネルギ一の割合を意味し， $F_{i j}$

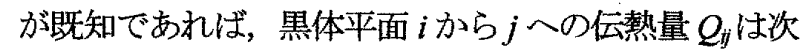
式で求められる.

$$
Q_{i j}=A_{i} \sigma\left(T_{i}^{4}-T_{j}^{4}\right) F_{i j}
$$

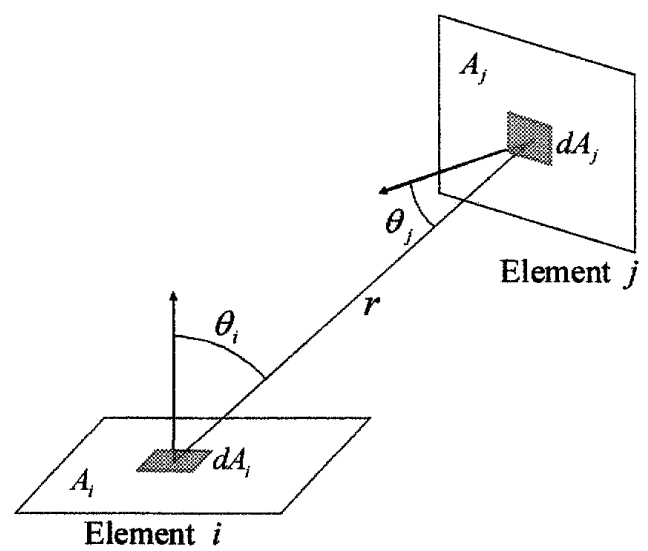

Fig. 1 Configuration between two plane elements

図 1 のような $2 つ の$ 要素間（解析モデルの分割要素の ことを本論文では要素と呼ぶ. CG 分野ではパッチと 呼ぶ場合がある）において，要素 $i ｊ$ の面積をそれぞ れ $A_{i}, A_{j}$ とし，要素に含まれる微小面積を $d A_{i}, d A_{j}$ と すると， $d A_{i}$ から $d A_{j} へ の$ 形態係数は次式となる.

$$
F_{d A_{i} d A_{j}}=\frac{\cos \theta_{i} \cos \theta_{j}}{\pi r^{2}} d A_{j}
$$

式(2)を $d A_{i}$ について積分することにより，要素 $i$ から 微小面積 $d A_{j}$ への形態倸数 $F_{i d d j}$ が次式で与えられる.

$$
F_{i d A_{j}}=\int_{A_{i}} \frac{\cos \theta_{i} \cos \theta_{j}}{\pi r^{2}} d A_{j} d A_{i}
$$

さらに，式(3)を $d A_{j}$ について積分することにより要素 $i$ から要素 $j$ への形態係数 $F_{i j}$ は次式の 2 重面積分で与 えられる.

$$
F_{i j}=\frac{1}{A_{i}} \int_{A_{i}} \int_{A_{j}} \frac{\cos \theta_{i} \cos \theta_{j}}{\pi r^{2}} d A_{i} d A_{j}
$$

式(4)より, $F_{i j}$ は要素間の幾何学的関係のみで決まる. 単純な幾何学形状面の組合せに対寸る $F_{i j}$ は図表・式に 絋められているが(2)，複雑形状面間では理論的に求め
ることが困難であり，面間に遮蔽物が存在する場合に は，取り扱いがさらに煩雑になる.

形態倸数の代表的な算出手法として，汎用性の高い モンテカルロ法(モンテカルロ・レイトレーシング法 $)^{(3}$ 〜)のほかに, 2 重面積分法 (7), Mitalas-Stephenson 法 ${ }^{(8)}$, CG 分野で広く用いられているへミキューブ法 ${ }^{(9)}$ など がある. 今野ら (7) は上記手法について建築環境工学で 扱う解析対象を想定した詳細な比較検証を行い，へミ キューブ法の高速性を指摘するとともに，大規模モデ ルにおいては計算時間の増加に対する精度の向上割合 が悪化することを報告している。一方，土井 ${ }^{(10)}$ は

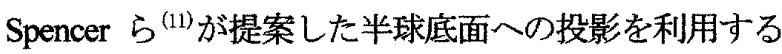
手法を改善することで，へミキューブ法の約半分の計 算時間で同質の画像生成が可能であることを報告して いる. 本論文では半球底面への投影を利用する手法を ヘミスフィア法と呼ぶこととする. ヘミスフィア法は ヘミキューブ法と同様に点対面間の形態係数算出法で あり，科学技術計算では適用例がなく，精度・計算時 間の検証や代表的な従来手法との比較が必要である.

2.2 ヘミスフィア法 式(4)において, 要素iの面 積 $A_{i}$ に対して要素間の距離 $r か ゙ 十$ 分大きいと仮定する と, 要素 $i$ から要素 $j$ に対する形態係数 $F_{i j}$ は次式で近 似できる.

$$
F_{i j} \approx \int_{A j} \frac{\cos \theta_{i} \cos \theta_{j}}{\pi r^{2}} d A_{j}
$$

この式は単位円の面積に対する投影された要素 $j$ の領 域の比率を表しているため,

$$
\frac{\cos \theta_{i} \omega_{i j}}{\pi}=\frac{\cos \theta_{i} \cos \theta_{j}}{\pi r^{2}} A_{j}
$$

と表すことができる. 式(6)と式(3)より，面積 $A_{j}$ の要素 $j$ から微小面積 $d A_{i}$ への形態係数は，微小面積 $d A_{i}$ を中 心とした半径 1 の半球の底面(スクリーンと呼ぶ)に, 面積 $A_{j}$ の要素 $j$ を図 2 中の $\mathrm{K}$ 部のように投影したとき の，K 部の面積に等しい。これはヌセルトの相似 (Nusselt's Analogy）として証明されている.この相似 則に基づいて，半球底面投影を用いて近似的に形態係 数 $F_{i j}$ を求める手法がへミスフィア法である. 主な処理 手順は次のようになる.

(1) 要素の頂点と辺をスクリーンへ投影する

(2) 投影された領域をセルに登録する

(3) セル面積より形態俰数を算出する

以下，各処理について述べる. 




Fig. 2 Nusselt's Analogy

要素形状の半球底面投影には，井上ら ${ }^{(12)}$ の解析的手 法を用いる。まず，要素頂点の半球底面への投影点を 求める. 半球底面の中心を原点とし, 底面を $x y$ 面，上 軸を $z$ 軸とする座標系を考える. 図 3 の任意要素 $j$ の 頂点 $p_{1}\left(X_{1}, Y_{1}, Z_{1}\right)$ の半球一の投影点座標 $p_{1}^{\prime}\left(x_{1}, y_{1}, z_{1}\right)$ は 要素頂点の単位べクトルとなり, 次式で表される.

$$
\left(x_{1}, y_{1}, z_{1}\right)=\left(X_{1} / L_{1}, Y_{1} / L_{1}, Z_{1} / L_{1}\right)
$$

$\Sigma$ こで,

$$
\begin{aligned}
& L_{1}=\sqrt{X_{1}^{2}+Y_{1}^{2}+Z_{1}^{2}} \\
& x_{1}^{2}+y_{1}^{2}+z_{1}^{2}=1
\end{aligned}
$$

半球底面への投影点は $p_{1} ”\left(x_{1}, y_{1}, 0\right)$ となる.

次に要素の各辺の投影を考える. 頂点 $p_{1}, p_{2}$ と原点 を通る平面で半球を切り，その切り口を半球底面に投 影する.このとき投影線は棈円の一部となる.この半 球底面への投影線の棈円方程式とその範用を求める. 要素㑯点 $p_{1}, p_{2}$ の空間座標を $\left(X_{i}, Y_{i}, Z_{i}\right)(i=1,2)$ とすれば, 半球を切る面の法線 $\left(X_{0}, Y_{0}, Z_{0}\right)$ は,

$$
\left(X_{0}, Y_{0}, Z_{0}\right)=\left(X_{1}, Y_{1}, Z_{1}\right) \times\left(X_{2}, Y_{2}, Z_{2}\right)
$$

であり，その上側法線の単位ベクトル $(l, m, n)$ は,

$$
\begin{aligned}
& Z_{0} \geq 0: l=X_{0} / L_{0}, \quad m=Y_{0} / L_{0}, \quad n=Z_{0} / L_{0} \\
& Z_{0}<0: l=-X_{0} / L_{0}, \quad m=-Y_{0} / L_{0}, \quad n=-Z_{0} / L_{0}
\end{aligned}
$$

となる.ここで,

$$
\begin{aligned}
& L_{0}=\sqrt{X_{0}{ }^{2}+Y_{0}{ }^{2}+Z_{0}{ }^{2}} \\
& l^{2}+m^{2}+n^{2}=1
\end{aligned}
$$

このとき, 半球底面への投影線は $n$ の值により分類で き, その方程式は次のようになる.

(i) $0<n<1$ の場合：棈円

$$
\frac{\left(l_{s} x+m_{s} y\right)^{2}}{n^{2}}+\left(-m_{s} x+l_{s} y\right)^{2}=1
$$

$\left(l_{s}, m_{s}\right)$ は棈円短軸方向の単位ベクトルで次式となる.

$$
\begin{aligned}
& l_{s}=-l / \sqrt{l^{2}+m^{2}} \\
& m_{s}=-m / \sqrt{l^{2}+m^{2}}
\end{aligned}
$$

(ii) $n=0$ の場合：原点を通る直線

$$
l x+m y=0
$$

(iii) $n=1$ の場合 : 円

$$
x^{2}+y^{2}=1
$$

半球底面に投影された軌跡の範囲は，それぞれの場合 について, 頂点 $p_{1}, p_{2}$ の半球底面への投影点 $p{ }_{1}\left(x_{1}, y_{1}\right)$, $p_{2}{ }_{2}\left(x_{2}, y_{2}\right)$ およひ $(l, m, n)$ に従って決定される.

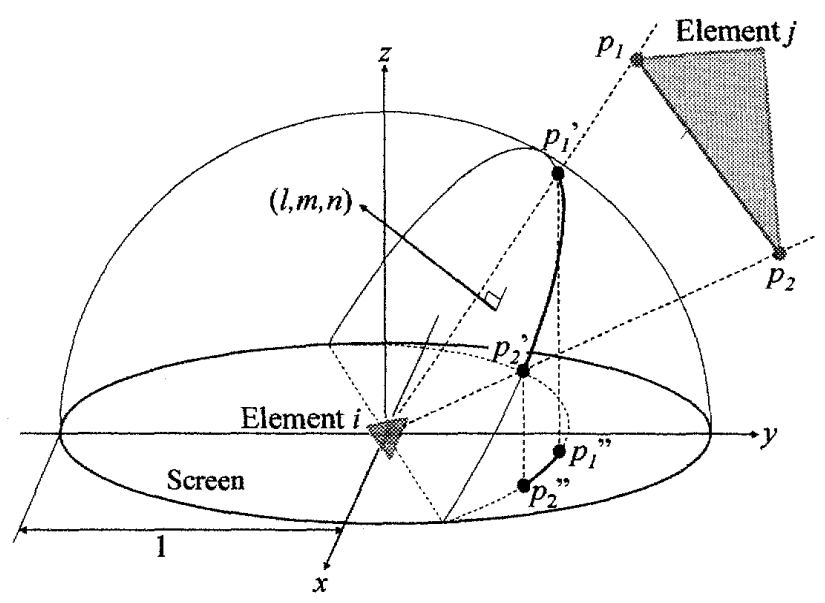

Fig. 3 Hemisphere projection onto bottom screen

次に要素の半球底面への投影面積を求めるために， 底面をセル分割し，各セルに投影情報を登録する．図 4 は正方形セルに分割した半球底面の投影スクリーン に要素が投影された例である。このように投影線に基 づい要素情報をセルに描画登録する，投影線をセル に登録するためには，スキャン変換と呼ばれる処理に より投影線をセルに置き換え, 投影領域を判別する(塗 りつぶす). スキャン変換には中点アルゴリズム ${ }^{(13)}$ 用いた，中点アルゴリズムの説明図を図 5 に示す。図 中の $0<$ 傾き $<1$ の線分 $\mathrm{AB}$ をスクリーンセルに登録 するスキャン変換を考える. 線分の始点 A から終点 B までをスクリーンセル(1) -(2) -(3)の順で登録していく 過程において，セル(1)の登録が終わり，セル(2)を判別 して登録する過程を解説する. まず，線分 $\mathrm{AB}$ とセル 中心を通る線分 X との交点を点 $Q$ とする. また, セル (2)とその下に隣接するセル(2)，との境界面の中点を点 $M$ とする. 中点アルゴリズムでは, 点 $Q \not ゙$ 中点 $M$ の 上下どちら側にあるかを判定する. 中点 $M$ が点 $Q$ よ り上にある場合，七ル(2) が線分に近く，中点 $M$ が点 
Qより下にある場合，セル(2)が線分に近い.この方法 で線分に最も近いセルを選択できる．また，選択され たセルの中心と線分との点 $Q$ との距離 (誤差) は常に $\leqq 1 / 2$ (セルの辺の長さを 1 とした場合）となる.中点 アルゴリズムの演算には計算時間を要する乗算がない ため高速である. 中点アルゴリズムは直線のほが円 および楕円にも適用できる.

このように選択された各セルには投影される要素 $j$ の番号と奥行き量（要素間距離 $r$ ) を登録する. 要素 を順次投影していき，ある要素が既に登録されている セルに投影された場合には，奥行き量が登録值よりも 小さい場合に登録情報を更新寸る。これにより空間内 に障害物がある場合の隠面消去処理が行なわれる．全 要素の登録後に各要素の登録セ儿数を求め, セル面積 から形態係数が算出される.



Fig. 4 Cell registration of projected elements on screen

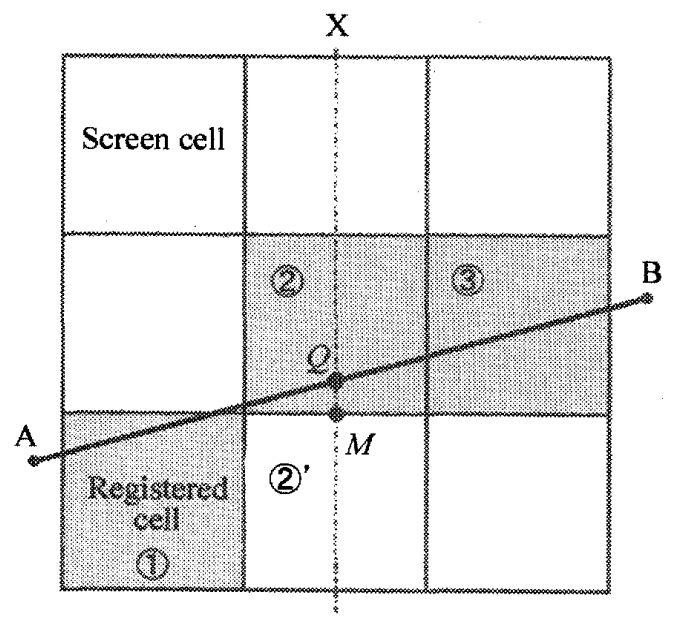

Fig. 5 Cell registration using median algorithm on screen

\section{3. ヘミスフィア法と従来手法との比較}

3.1 解析モデル 絶対誤差の評価のため, 解析 モデルには理論解が得られる立方体を用いた．図6に 解析モデルを示す，モデルを構成する単位要素当たり の寸法を $1 \times 1$ とし，立方体一辺の要素数を $1,5,11$, $15 ， 21 ， 25 ， 35 ， 45$ と変えることで，モデル全体の要 素数 $N=6,150,726,1350,2646,3750,7350,12150$ とした. また, 図 5 に示すように $F_{i j}$ 算出の基準となる 要素 $i$ (Sampling element) $の$ 位置は, 底面中央 (Case A)， 底面壁面寄り (Case B)，底面の角 (Case C) の3ケー スとした. 表 1 に解析に用いた計算機の仕様を示す. 精度および計算時間（CPU time）を比較する従来手法 としてモンテカルロ法および 2 重面積分法を用いた.

表 2 に各算出手法の計算精度・計算時間に影響を及 ぼす性能パラメータ「の設定条件を示す。へミスフィ ア法の場合はスクリーンセル数 (解像度), モンテカル 口法の場合は要素からの射出光線数，二重積分法の場 合は要素の再分割数が「である. 性能パラメータ「を大 きく設定すれば，いずれの手法においても計算精度が 向上し，逆に計算時間は増加寸る，基淮要素 $i$ から他 の要素 $j$ 全てへの形態係数 $F_{i j}$ を各ケース, 各算出手法, 解析条件で求め, 理論解との絶対誤差および計算時間



$$
F_{a b s_{-} \text {error }, j}=\left|F_{\text {analysis }, j}-F_{\text {calc }, j}\right|
$$

ここで, $F_{\text {anahsis }, j}$ は要素 $i$ から要素 $j$ への形態係数の理 論解， $F_{\text {catc }, j}$ は各手法で求めた形態係数である. また, 平均絶対誤差 $F_{\text {emor }}$ として次式を用いた。

$$
F_{\text {error }}=\left(\sum_{j=1}^{N} F_{\text {abs_error, } j}\right) / N
$$

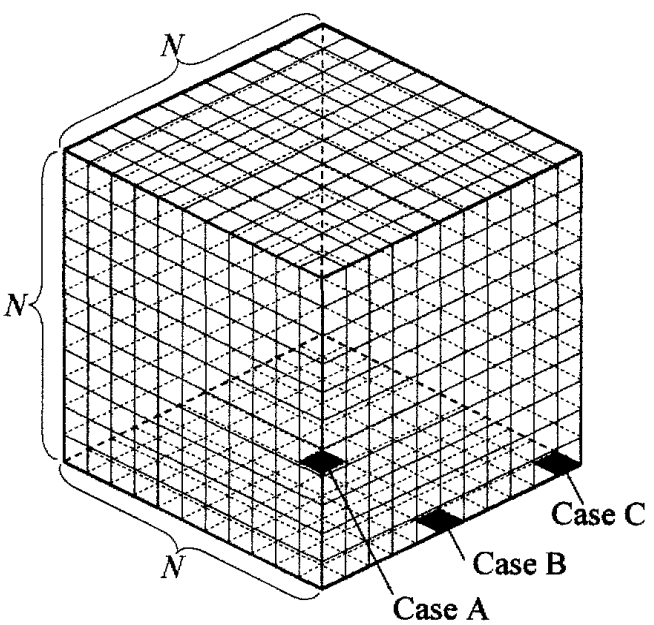

Fig. 6 Cubic model and three sampling elements 
3.2 解析結果の比较 図7に要素数 $N=150,7350$, 12150 において表2の性能パラメータ「を適用した際の 各手法の計算時間と平的絶対誤差の関係を示す。なお， 図中では各手法を表 2 記載の略称で示した。 Case B と Case C とでは顕著な相違がなかったため, Case Aおよ びCase B の結果を図 7(a)および(b)に示す. 図7より, ヘミスフィア法は他の手法に比べて要素数の増加によ る計算時間の増加がない，また，他の手法と同レベル の精度があり，要素数が多い場合に精度と計算時間の バランスにおいて有利である。例えば, Case A で要素 数 $N=12150$ の場合, 平均絶対誤差 $1.0 \times 10^{-5}$ 程度の形 態係数を求める時間は, 一ミスフィア法 $0.04 \mathrm{~s}$ に対し てモンテカルロ法と 2 重面積分法では約 1000 s を要す る. 基淮とする要素が立方体壁面寄りとなる Case B で は各手法ともに精度が低下しているが、へミスフィア 法は精度と計算時間のバランスを維持している.一方, 要素数が $N=150$ と少ない場合には, ヘミスフィア法の 精度は他の手法よりも劣化している. 要素数が少なく なると, 基準となる要素 $i$ の大きさに対して要素 $i$ と
要素 $j$ との要素間距離 $r$ が小さくなるため, $r$ 古十分大 きいことを前提として導出した式(5)を満たさなくな るため絶対誤差が大きくなる. 具体的には $r / a<2.5(a$ は要素の一辺の長さ, 本解析では $\sigma=1$ ）になると絶対 誤差のオーダーが $10^{-4}$ 以上になる. 要素数が多くなる と絶対誤差が大きい部分の面積が、相対的に小さくな るためモデル全体の平均絶対誤差が小さくなる，図 7 において Case B と Case C とで顕著な相違がない要因 も両ケースの $r$ が同じ傾向にあることに起因する. ま た, Case A と Case B とで HS(7350)と HS(12150)の平均 絶対誤差の傾向が異なる要因も, 両ケースの $r$ の傾向 の相違にある。

Table 1 Hardware specification used in performance test

\begin{tabular}{cc}
\hline $\mathrm{CPU}$ & Itanium2 $1.6 \mathrm{GHz}$ \\
\hline Program Language & $\mathrm{C}++$ \\
\hline Compiler & Intel $\mathrm{C}++$ compiler 8.1 \\
\hline
\end{tabular}

Table 2 Performance parameters of each algorithm used in performance test

\begin{tabular}{lll}
\hline \multicolumn{1}{c}{ Algorithm (abbreviation) } & Performance parameter & \multicolumn{1}{c}{ Value of parameter $\Gamma$} \\
\hline Hemisphere (HS) & Screen resolution, $\Gamma \times \Gamma$ & $\begin{array}{l}200,500,1000,2000,3000,4000, \\
6000,7000,8000,9000,10000\end{array}$ \\
\hline Monte Calro (MC) & $\begin{array}{l}\text { Amount of emitted rays } \\
\text { from an element, } \Gamma\end{array}$ & $\begin{array}{l}1 \times 10^{4}, 10 \times 10^{4}, \\
300 \times 10^{4}, 500 \times 10^{4}\end{array}$ \\
\hline Double Area Integral (DAI) & $\begin{array}{l}\text { Amount of subdivisions } \\
\text { on an element, } \Gamma\end{array}$ & $1,4,16$ \\
\hline
\end{tabular}



(a) Case A

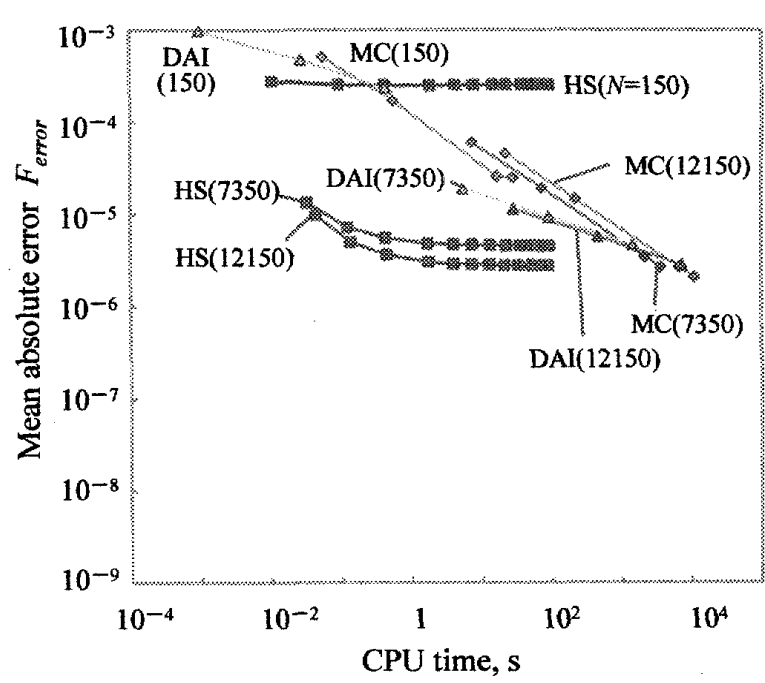

(b) Case B

Fig. 7 Mean absolute error and calculation time (CPU time) of three algorithms for $N=150,7350,12150$ 


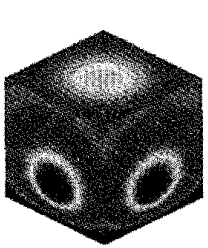

Theoretical

$$
F_{i j}
$$

$2.00 \times 10^{-04}$

$1.75 \times 10^{-04}$

$1.50 \times 10^{-04}$

$1.25 \times 10^{-04}$

$1.00 \times 10^{-04}$

$7.50 \times 10^{-0.5}$

$5.00 \times 10^{-0.5}$

$2.50 \times 10^{0.5}$

$0.00 \times 10^{+00}$


(a) Case A



Theoretical

$$
F_{i j}
$$

$2.00 \times 10^{-0.4}$

$1.75 \times 10^{04}$

$1.50 \times 10^{.04}$

$1.25 \times 10^{.04}$

$1.00 \times 10^{-04}$

$7.50 \times 10^{.05}$

$5.00 \times 10^{-05}$

$2.50 \times 10^{-0.5}$

$0.00 \times 10^{+00}$
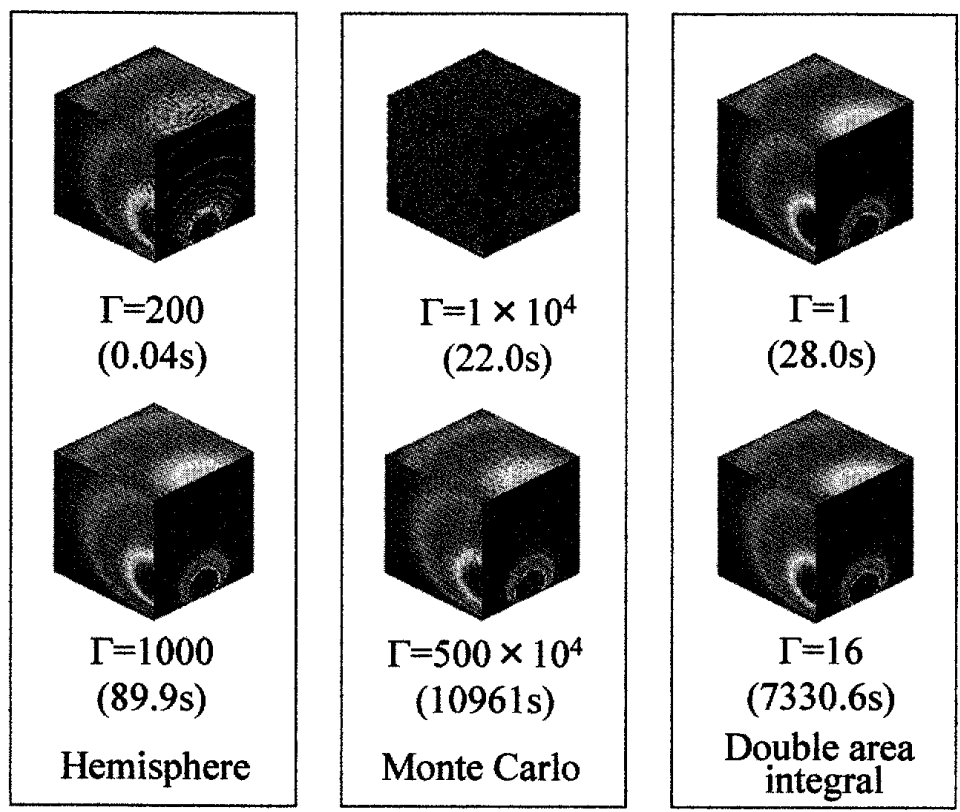

(b) Case B

Fig. 8 Comparison of form factor distribution and CPU time among analytical rigorous solution, Hemisphere, Monte Carlo and Double area integral algorithms in case of $N=12150$

Case B と Case Cでは, CaseA にくらべてrの小さい要 素の数が多く，それらの要素との幾何学的関倸 $\left(\theta_{i}\right.$ と $\theta_{j}$ ) も類似しているため, Case B と Case C の傾向はほ ほ同じになったと考えられる．また，本手法では $r$ が 小さくなると性能パラメータ「に関わらず，誤差が大 きくなる傾向があるため, Case B と Case C ではГを大
きくして計算時間を増やしても Case A よりも平均絶 対誤差が大きくなり，傾向の差異が現れたものと考え られる。

このように, へミスフィア法においては, rlaが誤差 に影響を及ぼす。とくに要素同士が隣接していて $r / a$ $<1$ で, 且つ $\theta_{i}<45^{\circ}, \theta_{j}<45^{\circ}$ の場合には, 本手法の大 
前提となっている式(5)で得られる形態係数は, 本来の 算出式(4)の值と大きく異なるため適用できない．また， 投影される要素の大きさに対してスクリーンセルが大 きくなると要素をスクリーンへ投影する際の誤差が大

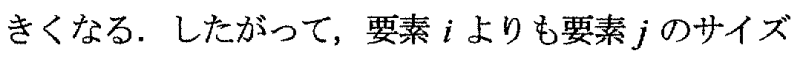
が大きく，且つ複雑形状であるようなモデルに対して は，これに応じてスクリーンセルを小さくし，スクリ ーンの解像度を上げる必要がある.

図 8 には, 要素数 $N=12150$ にお引ける理論解および各 手法によるCase A, Case B $の F_{i j}$ 分布図と計算時間を 示す。この分布図を作成する際には, 各要素を形態倸 数に応じた配色で塗りつぶし, 補間等の操作は行なっ ていない，モンテカルロ法では光線数の少ない高速計 算では分布状態が著しく劣化する. 二重積分法では, 分布状態の劣化はないが計算時間が長い．これに対し て、へミスフィア法では低スクリーンセル数において も高速かつ赛用性の女る分布状態が得られた。

モンテカルロ法では, 射出光線の入射要素を決める ために全要素 $j(j=1,2, \cdots, N)$ との交差判定をする必要が あるため, 光線数 $\times$ 要素数 $N$ の演算を要する. 精度を 高めるためには, 光線数を増やす必要がある.

2 重面積分法では, 再分割要素 $d A_{i}$ と $d A_{j}$ について全 要素 $k(k=1,2, \cdots, N)$ との交差判定を行うため, $N^{2} \times\left(d A_{i}\right.$ の数 $\times d A_{j}$ の数)の演算を要する. 精度を高めるために は再分割数を増やす必要があり，大規模モデルの解析 には計算時閒の点で向かない.

ヘミスフィア法では $N$ 回の投影とセル登録で斉むた め, 投影に要する演算量が本質的に少ない，セル登録 に要する時間はスクリーンセル数に依存する．このた め, 要素数が増加しても他の手法のような計算時間の 著しい増大はない，ただし，図7のようにスクリーン セル数の増加に対する精度の向上割合は収斂する傾向 がある．また，他の手法に比べて計算精度が方向によ らず空間全体で均一になる傾向がある。

3 -3 遮葆物がある堨合の比较 大規模解析では 任意形状物体が任意の位置に存在するのが一般的であ るため, 複雑形状の遮蔽物が存在するモデルにおける 各手法の性能を検証すべきである. しかし，そのよう なモデルでは理論解を求めることが困難なため, 精度 は相対的な比較にならざるを得ない，実際の工業的な 熱解析設計の現場では, 解析結果を逐次可視化ソフト ウェアで出力し, 可視結果の分布状態に基づいて設計 解析を進めるケースが多い. 以上の観点から，遮蔽物 があるモデルについて各手法で求めた形態係数分布の 分布状態および計算時間を比較する.

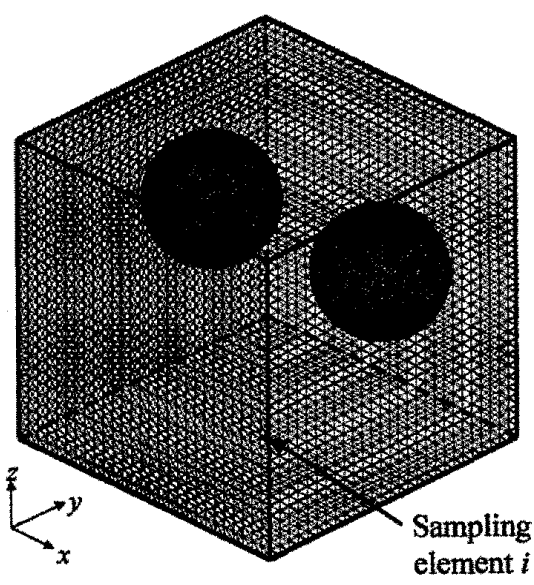

Fig. 9 Cubic model includes two spheres as obstacle

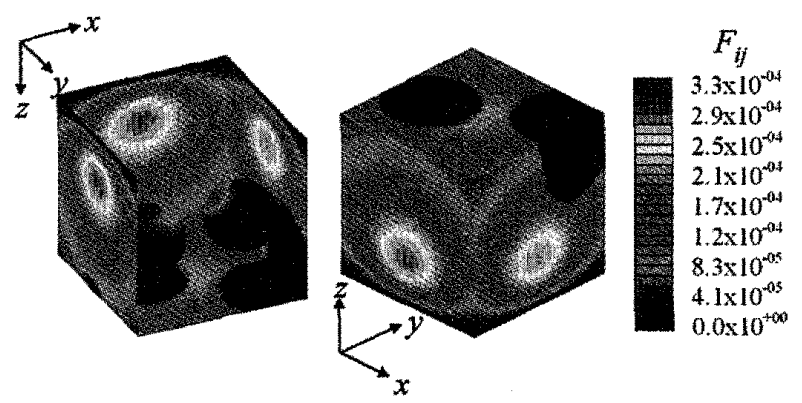

(a) Hemisphere (CPU time $=8.9 \mathrm{~s}$ )



(b) Monte Carlo (1851s)
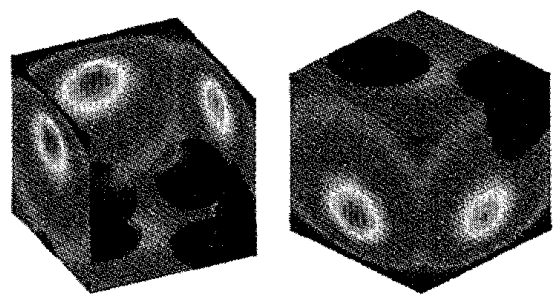

(c) Double area integral (7982s)

Fig. 10 Comparison of form factor distribution and CPU time among Hemisphere, Monte Carlo and Double area integral algorithms in case as shown in Fig.6

図 9 に示寸ような，立方体の内部に $2 つ$ つ球を配置 した要素数 $N=16684$ のモデルを用いた. モデルはすべ て三角形要素で構成されている. 底面中央の基淮要素 $i$ から他のすべての要素 $j$ への $F_{i j}$ をへミスフィア法, モンテカルロ法, 2 重面積分法で求めた. ヘミスフィ ア法はスクリーン解像度 $4000 \times 4000$, モンテカルロ法 
は射出粒子数 $500 \times 10^{4}, 2$ 重面積分法は $d A$ 数 16 と設 定して形態保数算出を行った.

図 10 に各手法で求めた $F_{i j}$ 分布を示寸．図より，す べての手法でほぼ同様の分布が得られているが，計算 時間はへミスフィア法:8.9s, モンテカルロ法: 1851s,

2 重面積分法 : 7982s であり, ヘミスフィア法の高速性 が示された．分布状態も良好である.

以上の結果から, ヘミスフィア法は要素数の多い大 規模なモデルの形態係数の算出において, $1.0 \times 10^{-5}$ 程度の平均絶対誤差を許容できるのならば效率的な手 法である. とくに要素数の多、場合において, 精度・ 計算時間の優位性があるため，大規模モデルにおろる 試行錯誤計算に適している。 なお，滝沢ら ${ }^{(14)}$ は，人ミ スフィア法をグラフィックス描画演算専用のハードウ エア (GPU) に実装することで，通常の CPU 演算以 上に高速演算できることを報告している．また，本研 究では灰色面間のふく射伝熱解析における検証を行っ たが，ランバートの法則が各波長について適用できる 場合には，非灭色面間の解析にもへミスフィア法を適 用できる，空間中にふく射性媒体がある場合には，媒 体による吸収の影響は透過距離を用いて考慮できるが， ふく射性媒体からの放射の取り扱いは困難である.

\section{4. 䊀}

ヘミスフィア法による形態係数算出の優位性の有無 について性能検証を行った. 解析モデルは, 工学の広 い対象に対する普遍性·網羅性の点で十分ではないが， 検証した範囲に㧈いて，以下の知見を得た。

(1)へミスフィア法では, モンテカルロ法や 2 重面積分

法に比べて, 要素数の増加による計算時間の著しい 増加がなく, 要素数が多い場合に精度と計算時間に おいて優位性が認められた。

(2)スクリーンセル数 (解像度) を下げて高速化した場 合においても形態係数分布状態の劣化が少なく, 要 素数の多い大規模モデルの試行錯誤計算に適する. 今後, グラフィックス専用ハードウェアとの併用で ふく射伝熱解析の高速・効率化が期待される.

\section{文苚}

(1) Pharr, P. and Humphreys, G, Physically Based Rendering, Morgan Kaufmann Publishers, (2004)

(2) Siegel, R. and Howell, J., A Catalog of Radiation Heat Transfer Configuration Factor, Thermal Radiation Heat Transfer, 4th Edition, Taylor and Francs (2002)

(3) Omori, T. et al., Radiative Heat Transfer Analysis Method for Coupled Simulation of Convection and Radiation in Large-Scale and Complicated Enclosures, Transactions of the Society of Heating, Air-Conditioning and Sanitary Engineers of Japan, No.88 (2003), pp.103-113.

(4) Omori, T. et al., Prediction Method of Radiant Environment in a Room and its Application to Floor Heating, Transactions of the Society of Heating, Air-Conditioning and Sanitary Engineers of Japan, No.42 (1990), pp.9-18.

(5) Murakami, S. et al., Numerical Study on Thermal Environment in Air-conditioned Room by means of Coupled Simulation of Convective and Radiative Heat Transport, No.59 (1995), pp.95-104.

(6) Yang, W. J., Taniguchi, H. and Kudo, K., Radiative Heat Transfer by the Monte Carlo Method, Advances in Heat Transfer, Vol.27 (1995), Academic Press, San Diego.

(7) Konno, M. et al., Study on Calculation Method of View Factors in Radiant Heat Transfer Analysis, Journal of Environmental Engineering, $A I J$, No.572 (2003), pp.17-22.

(8) Mitalas, G.P. et al., Fortran IV Programs to Calculate Radiant Interchange Factors, Technical Report BDR-25, National Research Council of Canada, Division of Building Research (1966)

(9) Cohen, M.H. and Greenberg, D.P., The Hemi-cube: Radiosity Solution for Complex Environments, Computer Graphics, Vol.19, No.3 (1985), pp.31-41.

(10) Doi, A., Hemi-sphere Base Projection Method for Calculating Form Factor and Its Parallelization for Radiosity, Journal of the Institute of Image Electronics Engineers in Japan, Vol.24, No.3 (1995), pp.189-195. (in Japanese)

(11) Spencer, S. N., The Hemisphere Radiosity Method : A Tale of Two Algorithms, Photorealism in Computer Graphics, Springer (1992), pp.127-135.

(12) Inoue, T. et al., Analytical Estimation of Form Factors in Radiosity Method, Research Reports of Kanagawa Institute of Technology, Part B, Science and Technology, No.22 (1998), pp.107-110.

(13) Foley, J. D. et al., Computer Graphics: Principles and Practice, Addison-Wesley Educational Publishers Inc. (1995)

(14) Takizawa, H., Yamada, N., Sakai, S. and Kobayashi, H., Radiative Heat Transfer Simulation Using Programmable Graphics Hardware, Proceedings of the 5th IEEE/ACIS International Conference on Computer and Information Science (2006), pp.29-36. 